\title{
ELEKCJE MARSZAŁKÓW POSELSKICH NA SEJMACH W OKRESIE PANOWANIA MICHAŁA KORYBUTA WIŚNIOWIECKIEGO - ZARYS PROBLEMATYKI
}

\begin{abstract}
ELECTIONS OF SEJM MARSHALS IN THE TIMES OF MICHA£ KORYBUT WIŚNIOWIECKI'S RULE - PRESENTATION OF RESEARCH TOPIC

The article presents the outline of the research project on the elections of sejm Marshalls in the years 1669-1672. Only the last sejm assembled during Michał Korybut Wiśniowiecki’s reign was omitted due to its specificity - it was the 1673 pacification sejm. Various elements of the parliamentary procedures such as the initiation of the election, deputies' attendance, the exchange between the Crown and Grand Duchy of Lithuania in fulfilling functions and proposing candidates to these functions, removal of deputies and finally the form of voting are taken into connsideration and discussed. Sejm diaries form the source base for the research, which is supplemented with existing historiography.
\end{abstract}

Key words: Michał Korybut Wiśniowiecki, Sejm Marshall, Sejm, election

Słowa kluczowe: Michał Korybut Wiśniowiecki, marszałek izby poselskiej, sejm walny, elekcja

Problematyka elekcji marszałków poselskich była już niejednokrotnie obiektem zainteresowania historyków. Jak dotąd element ten był analizowany szczegółowo w odniesieniu do sejmów z czasów Zygmunta III Wazy, Władysława IV Wazy i Jana III Sobieskiego.

1 W. Kaczorow ski, Wybór marszatków poselskich na sejmach bezkrólewia 1632 roku, „Zeszyty Naukowe WSP w Opolu. Historia" 1986, t. 23, s. 33-41; J. S e r e d y k a, Elekcje marszatków poselskich za Zygmunta III Wazy (1587-1632), [w:] Studia z dziejów Rzeczypospolitej szlacheckiej, red. K. Matwijowski, Z. Wójcik, Wrocław 1988, s. 95-112, Acta Universitatis Wratislaviensis, nr 945, Historia, t. 66; id e m, Marszat- 
Podobne analizy do czasów Jana Kazimierza oraz bezkrólewia po jego abdykacji można znaleźć w opracowaniach Stefanii Ochmann-Staniszewskiej, Zdzisława Staniszewskiego oraz Jarosława Stolickiego ${ }^{2}$. Tego typu rozważań nie doczekały się natomiast sejmy z okresu rządów Michała Korybuta Wiśniowieckiego. Niniejszy artykuł ma na celu zasygnalizowanie tej poważnej luki badawczej i - w oparciu o wybrany materiał źródłowy - wstępne przedstawienie elementów procedury związanych ze sposobem wyboru dyrektora izby poselskiej w okresie panowania pierwszego króla rodaka. Analiza obejmuje pięć sejmów z lat 16691672. Z oczywistych przyczyn pominięto natomiast sejm pacyfikacyjny z 1673 r., podczas którego nie przeprowadzono aktu wyboru marszałka, którym został, zgodnie z wcześniejszymi ustaleniami, marszałek konfederacji gołąbskiej Stefan Stanisław Czarniecki³.

Procedura elekcji marszałka zaczynała się zaraz po zakończeniu mszy inaugurującej obrady. Z analizy sejmów z pierwszej połowy XVII w. wiadomo, że pierwsza sesja rozpoczynała się około godziny jedenastej ${ }^{4}$. W późniejszym okresie obrady przeciągały się nawet do wczesnych godzin popołudniowych ${ }^{5}$. Do czasu uchwalenia w 1690 r. odpowiedniej konstytucji ${ }^{6}$ nie istniało żadne ograniczenie regulujące czas elekcji marszałka. W czasach panowania Wazów kończyła się ona najczęściej pierwszego dnia, zaledwie po kilku godzinach obrad $^{7}$. Dłuższe elekcje były opisywane w diariuszach jako wydarzenia niezwykłe. Istniały jednak pojedyncze przypadki, w których wybór przeciągał się nawet do kilku lub kilkunastu $\mathrm{dni}^{8}$.

Z pewnością cechą charakterystyczną pierwszych dni obrad sejmowych była nieobecność przedstawicieli wielu powiatów i ziem9 ${ }^{9}$ Zdarzały się przypadki, że na obrady stawiła

kowie izby poselskiej za Zygmunta III Wazy, [w:] Wtadza i spoteczeństwo w XVI i XVII w. Praca ofiarowana Antoniemu Maczakowi w sześćdziesiątą rocznicę urodzin, red. M. Ka m le r [et al.], Warszawa 1989, s. 166; R. Koło d zi i j, Elekcje marszatków poselskich w czasach panowania Jana III Sobieskiego (1676-1695), [w:] Ustrój - polityka - kultura. Studia ofiarowane Profesor Stefanii Ochmann-Staniszewskiej, red. J. Ma ro ń, R. Kołodziej, Wrocław 2011, s. 77-94.

2 S. Ochmann-Staniszewska, Z. Stan iszew ski, Sejm Rzeczypospolitej za panowania Jana Kazimierza Wazy. Prawo - doktryna - praktyka, t. 2, Wrocław 2000, s. 130-149; J. S tol ick i, O wyborze marszatka poselskiego podczas sejmu elekcyjnego 1669, [w:] Poprzez stulecia. Ksiega pamiątkowa ofiarowana profesorowi Antoniemu Podrazie w 80. rocznicę Jego urodzin, red. D. Czersk a, Kraków 2000, s. 85-92.

3 L. A. W ie rzbicki, O zgodęw Rzeczypospolitej. Zjazd warszawski i sejm pacyfikacyjny 1673 roku, Lublin 2005, s. 217.

4 J. Seredyka, W. Kaczorow ski, Marszatkowieposelscy za Wtadystawa IV, [w:] Kultura, polityka, dyplomacja. Studia ofiarowane Profesorowi Jaremie Maciszewskiemu w sześ́dziesiąta rocznice jego urodzin, red. A. Bartnicki [et al.], Warszawa 1990, s. 348-349.

5 S. Ochmann-Staniszewska, Z. Staniszewski, op.cit., s. 145.

6 „Objaśnienie konstytucyi dawniejszych o porządku sejmowania”. Volumina legum, t. V, Warszawa 1859, s. 371. Według tej konstytucji marszałek miał być obierany pierwszego dnia obrad.

7 J. Se redyka, Elekcje marszatków poselskich..., s. 96.

$8 \quad$ Ibidem, s. 97.

9 Zazwyczaj w pierwszych dniach sejmu na obrady stawiało się średnio, w zależności od okresu, od 50 
się więcej niż połowa z nich, ale nie były one normą ${ }^{10}$. Zgodnie z ówczesną praktyką niska frekwencja nie przeszkadzała jednak w przeprowadzeniu elekcji, co znacznie usprawniało i przyspieszało cały proces.

Analiza przebiegu sejmów z lat 1669-1672 pokazuje tendencję do coraz późniejszego przystępowania do elekcji marszałka. Zarówno podczas sejmu koronacyjnego w 1669 r., jak i sejmu nadzwyczajnego w 1670 r. obrady rozpoczęły się o godzinie drugiej po południu $^{11}$. Na kolejnym sejmie z 1670 r. posłowie pojawili się w izbie o godzinie trzynastej ${ }^{12}$, zaś na sejmie zwyczajnym w 1672 r. dopiero „o godzinie trzecij z południa” ${ }^{13}$. Na drugim sejmie w 1672 r. obrady rozpoczęły się po raz kolejny o godzinie trzynastej ${ }^{14}$.

Podczas sejmu w 1669 r. marszałek został wybrany, po krótkiej dyskusji, pierwszego dnia obrad ${ }^{15}$. Inaczej wyglądało to na pierwszym sejmie z 1670 r., na którym, ze względu na dyskusję w izbie dotyczącą rozdania gospód oraz sporów dotyczących wyrugowania posłów będących deputatami do konstytucji na sejmie z 1667 r., marszałka obrano dopiero po trzech dniach $^{16}$. Na sejmie zwyczajnym w 1670 r. mamy do czynienia z wyjątkowo szybką elekcją, która zakończyła się już po godzinie ${ }^{17}$. Znacznie dłużej trwała ona w przypadku pierwszego sejmu w 1672 r., kiedy to dyrektora izby obrano po raz kolejny dopiero trzeciego dnia ${ }^{18}$. O nadzwyczajności takiego rozwiązania przekonany był pamiętnikarz Jan Antoni Chrapowicki, który zauważył, iż wybór został dokonany „aż trzeciego dnia” ${ }^{19}$. Dowodzi to, że w dalszym ciągu przeciąganie się elekcji było uznawane za wydarzenie niezwykłe. Na drugim sejmie w 1672 r. wyboru marszałka dokonano drugiego dnia obrad. Powodem opóźnienia były oskarżenia wysuwane przez zakon jezuitów pod adresem Stefana Piaseczyńskiego, starosty bracławskiego. Jezuici zarzucali posłowi, że ciąży na nim banicja orzeczona w Trybunale Koronnym, związana z procesem dotyczącym podziału majątku

posłów za czasów Zygmunta III, przez 60 za Władysława IV Wazy, aż do 72 za Jana Kazimierza. Zob. S. Ochmann-Staniszewska, Z. Staniszewski, op. cit., s. 141.

10 Na sejmie 1619 r. na sali obrad w pierwszym dniu stawiło się ponad 100 posłów, co stanowiło ok. 55\% całego składu izby poselskiej. Zob. J. S e re d y ka, Elekcje marszatków poselskich..., s. 99.

11 Diariusz sejmu koronacyjnego 1669 roku, oprac. K. Pr zyboś, M. Ferenc, Kraków 2004, s. 3; Diariusz sejmu nadzwyczajnego 1670 roku, oprac. K. Pr zy b oś, M. Fe re n c, Kraków 2004, s. 3.

12 Diariusz sejmu zwyczajnego 1670 roku, oprac. K. Pr zyb oś, M. Fe re n c, Kraków 2005, s. 3.

13 Diariusz sejmu zwyczajnego 1672 roku, oprac. K. Pr zy b oś, Kraków 2007, s. 4.

14 Biblioteka Zakładu Narodowego im. Ossolińskich we Wrocławiu [dalej: B. Ossol.], 247, k. 213v: Diariusz sejmu warszawskiego zaczętego in Anno 1672 die 18 Maii.

15 Diariusz sejmu koronacyjnego..., s. 5.

16 Diariusz sejmu nadzwyczajnego..., s. 7.

17 Diariusz sejmu zwyczajnego 1670..., s. 4.

18 Diariusz sejmu zwyczajnego 1672..., s. 10.

19 J. A. Chrapowicki, Diariusz. Część trzecia: lata 1669-1673, oprac. L. Wi er zbicki, Warszawa 2009, s. 196. 
po jego zmarłym bracie, do którego to majątku pretensje zgłaszał trzeci z braci, członek zakonu jezuitów ${ }^{20}$. Oskarżenia te skutecznie zatamowały przebieg obrad.

W przypadku kilku sejmów, na podstawie wykorzystanych diariuszy, nie jest możliwe precyzyjne określenie, ilu posłów wzięło udział w elekcji marszałka. Dokładna liczba głosujących pojawia się w relacji z sejmu koronacyjnego z 1669 r., na którym jednomyślnie wybrany marszałek otrzymał 127 głosów ${ }^{21}$. Frekwencja była więc tym razem bardzo duża, jednak nie powinna dziwić w przypadku sejmu, którego inaugurację poprzedzały uroczystości koronacyjne nowego monarchy. Na sejmie nadzwyczajnym w 1670 r. na poszczególnych kandydatów oddano w sumie 83 „kreski”22. Być może wyższa frekwencja była na drugim sejmie w 1670 r., gdyż autor diariusza zanotował, że przystąpiono do elekcji: „in abundanti numero pp. posłów” ${ }^{23}$. Zgodnie z relacją z sejmu zwyczajnego w 1672 r. liczba posłów na mszy inaugurującej obrady była „mierna”, podczas gdy marszałek „starej laski” Stanisław Herakliusz Lubomirski w swojej mowie gratulował posłom wysokiej frekwencji ${ }^{24}$. Te sprzeczne informacje dość łatwo wytłumaczyć. Lubomirski w swoim przemówieniu zapewne posłużył się figurą retoryczną, dlatego też bardziej wiarygodna zdaje się informacja dotycząca udziału w mszy świętej. Oczywiście nie wiadomo, czy wszyscy posłowie stawili się na mszy, ale grupa nieobecnych nie mogła być aż tak liczna, żeby znacząco zwiększyć frekwencję na sali sejmowej. Trudno stwierdzić, ilu posłów było na sali w momencie wyboru marszałka trzeciego dnia obrad, można jednak zakładać, że frekwencja wzrosła. Nie mamy również dokładnej informacji o liczbie posłów biorących udział w elekcji marszałka na drugim sejmie w 1672 r., gdyż diariusz informuje tylko, że frekwencja była „niewielka”25.

Problemem ściśle związanym z wyborem marszałka była kwestia rugów poselskich. Czasami spory dotyczące decyzji, czy usunąć jakiegoś posła z izby lub którą delegację z rozdwojonego sejmiku uznać za „prawdziwą”, wydłużały elekcje. Możliwe było przyznanie każdemu składowi poselskiemu połowy głosów przysługujących danemu sejmikowi bądź dobrowolna rezygnacja $z$ udziału w elekcji ${ }^{26}$. Teoretycznie odprawianie rugów nie powinno się odbywać przed elekcją. W praktyce sejmowej utarło się bowiem, że przed obiorem marszałka sejm znajduje się w stanie passivitas i nie może podejmować wiążących decyzji. Z drugiej strony, jeśli posłów faktycznie usunięto, ale dopiero po elekcji, to brali oni w niej bezprawnie udział. Kwestię rugów rozwiązywano na bieżąco na każdym sejmie. Jedynie w przypadku dwóch

20 B. Ossol., 247, k. 213v: Diariusz sejmu warszawskiego...

21 Jeśli sam wybrany, Stanisław Krzycki, podkomorzy kaliski, oddał, zgodnie ze zwyczajem, głos na innego posła, można zakładać, że na sali obrad było 128 posłów. Diariusz sejmu koronacyjnego..., s. 5.

22 Diariusz sejmu nadzwyczajnego..., s. 8.

23 Diariusz sejmu zwyczajnego $1670 \ldots$, s. 3.

24 Diariusz sejmu zwyczajnego 1672..., s. 4.

25 Diariusz Seymu [drugiego] Roku Tysiąc Sześćset Siedmdziesiąt wtórego, miesiąca Maja, dnia ośmnastego, [w:] Pisma do wieku i spraw Jana Sobieskiego, t. I, cz. 2, wyd. F. Klu c z y cki, Kraków 1881, s. 889.

26 J. S e red y k a, Elekcje marszatków poselskich..., s. 97-98. 
sejmów z tego okresu można znaleźć informacje o rozpatrywaniu rugów przed wyborem dyrektora izby. W trakcie pierwszego sejmu w 1670 r. pojawiły się głosy, aby usunąć z izby posłów, którzy byli deputatami do konstytucji na sejmie w 1667 r. Zakwestionowana została także ważność mandatu Jana Krasińskiego, referendarza koronnego. Według posłów sandomierskich było to świadome opóźnianie wyboru marszałka, aby obrady sejmu zakończyły się porażką ${ }^{27}$. W 1672 r., o czym wspomniano wyżej, z zarzutami w stronę Stefana Piaseczyńskiego, starosty bracławskiego, wystąpili jezuici, twierdząc, że na pośle ciąży kondemnata. Protest nie został jednak uznany przez izbę i starosty nie rugowano ${ }^{28}$.

Istotnym problemem związanym z elekcją marszałka była alternata prowincji w sprawowaniu tej funkcji. Według Wacława Uruszczaka w początkach działalności sejmu izba posiadała dwóch przedstawicieli, po jednym z Małopolski i Wielkopolski ${ }^{29}$. Później prawdopodobnie zasadę tę przekształcono w taki sposób, że marszałek był wybierany na zmianę spośród posłów jednej z prowincji. Od 1569 r. do alternaty, jako trzecią prowincję, dołączono Wielkie Księstwo Litewskie. Jeszcze w czasach Zygmunta III Wazy kwestią problematyczną w przypadku ustalania alternaty było rozwiązanie sporu, czy wliczać do niej należy również sejmy nadzwyczajne i niedoszłe. Ostatecznie, mimo protestów Litwinów, zarówno jedne, jak i drugie zgromadzenia zostały uznane za wliczające się do alternaty ${ }^{30}$. W 1673 r., a więc już poza analizowanym okresem, alternata laski marszałkowskiej została dodatkowo połączona z alternatą miejsca obrad. Od tego czasu na sejmie odbywającym się w Grodnie marszałkiem miał być zawsze Litwin ${ }^{31}$.

Jeśli chodzi o alternatę prowincji w okresie panowania Michała Korybuta, trzeba stwierdzić, iż była ona konsekwentnie przestrzegana. Na sejmie koronacyjnym marszałkiem został przedstawiciel Wielkopolski Stanisław Krzycki, podkomorzy kaliski ${ }^{32}$. W trakcie obrad pierwszego sejmu w 1670 r. dyrektorem obrano Litwina Jana Kazimierza Kierdeja $^{33}$. Na sejmie w 1670 r. marszałkiem wybrany został przedstawiciel Małopolski, poseł sejmiku opatowskiego - Stanisław Herakliusz Lubomirski ${ }^{34}$. Podczas sejmu zwyczajnego

27 Diariusz sejmu nadzwyczajnego..., s. 6, 8.

28 Diariusz Seymu [drugiego]..., s. 889.

29 W. Uruszczak, Sejm walny koronny w latach 1506-1540, Warszawa 1980, s. 161, przyp. 61.

30 Zob. J. D o rob is z, Z problematyki procedury sejmów nadzwyczajnych za Zygmunta III, [w:] Studia z dziejów Rzeczypospolitej szlacheckiej, s. 135; S. Ochmann-Staniszewska, Z. Staniszewski, op. cit., s. 132.

31 H. Olszew ski, Sejm Rzeczypospolitej epoki oligarchii 1652-1763. Prawo - praktyka - teoria - programy, Poznań 1966, s. 36-38.

32 Diariusz sejmu koronacyjnego...., s. 5. Krótkie biografie wszystkich marszałków z omawianego okresu przedstawił niedawno: L. W i e r z b i ck i, Marszatkowie i parlamentarzyści. Studia z dziejów sejmu polskiego wXVII w. Warszawa 2014, s. 48, 53, 58, 63, 89.

33 Diariusz sejmu nadzwyczajnego..., s. 7.

34 Diariusz sejmu zwyczajnego 1670..., s. 4. 
w 1672 r. wybrano Marcina Oborskiego, starostę liwskiego ${ }^{35}$, który był przedstawicielem prowincji wielkopolskiej. Na następnym sejmie marszałkiem obrany został Litwin - Michał Leon Sokoliński ${ }^{36}$.

Osobą, która miała zagaić i przeprowadzić elekcję, winien być marszałek „starej laski”, czyli marszałek poprzedniego sejmu. Mogła jednak wystąpić sytuacja, w której poprzedni dyrektor izby nie brał udziału w obradach kolejnego sejmu ${ }^{37}$. Teoretycznie marszałek, który nie zyskał mandatu na kolejny sejm, nie mógł przewodniczyć obradom, ale w praktyce, jeśli stawił się na sejm, pozwalano mu na zagajenie ${ }^{38}$. W przypadku nieobecności dyrektora „starej laski” konieczne było wybranie zastępcy. Zostawał nim poseł z „górnego” województwa tej samej prowincji, co marszałek „starej laski”39. Aż do panowania Jana Kazimierza w większości przypadków, dla których znany jest przewodniczący elekcji, był nim marszałek poprzedniego sejmu ${ }^{40}$. Później nie trzymano się już konsekwentnie zasad dotyczących wyboru zastępcy marszałka. Nie zawsze był to przedstawiciel „górnych” województw, a nawet czasami nie był to poseł z tej samej ziemi, co marszałek ${ }^{41}$.

Na sejmie koronacyjnym 1669 r. elekcji przewodniczył marszałek poprzedniego sejmu, Szczęsny Feliks Potocki, co nie wywołało żadnych protestów ze strony posłów ${ }^{42}$. Podobnie rzecz się miała na obu sejmach w $1670 \mathrm{r}^{43}$ Sytuacja komplikowała się w przypadku sejmu w 1672 r., gdyż Lubomirski nie był posłem swojej ziemi na sejm. Część izby sugerowała, że powinien się on zrzec przewodniczenia elekcji na rzecz jednego z posłów ze swojego województwa lub z „górnego” województwa prowincji, z której się wywodzi1 ${ }^{44}$. Zgodnie $\mathrm{z}$ informacjami zawartymi w jednym $\mathrm{z}$ diariuszy sejmu posłowie $\mathrm{w}$ końcu odstąpili od swoich obiekcji ${ }^{45}$. Dzięki temu ostatecznie Lubomirskiemu przypadł honor przekazania laski nowemu marszałkowi ${ }^{46}$.

W przypadku sejmu nadzwyczajnego w 1672 r. po raz kolejny zaistniała sytuacja, w której poprzedni dyrektor izby, Marcin Oborski, nie został wybrany posłem swojej ziemi na

35 Diariusz sejmu zwyczajnego 1672..., s. 10.

36 Diariusz Seymu [drugiego]..., s. 889. Co ciekawe, marszałkiem kolejnego sejmu, czyli sejmu pacyfikacyjnego, został Stefan S. Czarniecki jako marszałek konfederacji gołąbskiej, ale jako przedstawiciel prowincji małopolskiej również przewodniczył obradom zgodnie z alternatą prowincji.

37 Szerzej na ten temat zob. S. O ch mann-Stan is zew ska, Z. Stan is zew ski, op. cit., s. 133-134.

38 H. Olszewski, op. cit., s. 196.

39 J. Sered yka, Elekcje marszatków poselskich...s. 101-102.

40 J.Seredyka, W. Kaczorowski, op. cit., s. 350.

41 S. Ochmann-Stan is zewska, Z. Stan iszewski,op. cit., s. 134.

42 Diariusz sejmu koronacyjnego..., s. 3.

43 Diariusz sejmu nadzwyczajnego..., s. 3; Diariusz sejmu zwyczajnego 1670..., s. 3.

44 Diariusz sejmu zwyczajnego 1672..., s. 6-9.

45 Ibidem, s. 10.

46 [Inny, krótszy dziennik Sejmu styczniowego, r. 1672], [w:] Pisma do wieku i spraw..., s. 839. 
kolejny sejm. W jednej relacji z tego sejmu można znaleźć informację, że Oborski, zamiast od razu przystąpić do prowadzenia obrad, zasiadł w ławie z posłami swojego województwa. Miało to wzbudzić uznanie całej izby, która zgodnie pozwoliła mu zainaugurować i poprowadzić obrady ${ }^{47}$. W innej relacji z tego samego sejmu można jednak znaleźć informację, że decyzja ta wywołała pewne kontrowersje. W ich efekcie, w drugim dniu obrad, jeden z posłów litewskich, Kazimierz Dąbrowski, pisarz grodzki wileński, wystąpił z propozycją uchwalenia prawa, na mocy którego marszałek starej laski, który nie zostanie ponownie wybrany posłem, nie będzie mógł przewodniczyć elekcji nowego dyrektora izby. Pomysł uzyskał aprobatę całej izby ${ }^{48}$, lecz zerwanie sejmu nie pozwoliło na jego uchwalenie. W przypadku obu sejmów w 1672 r. widać wyraźnie, iż posłowie nieprzychylnie patrzyli na jakikolwiek aktywny udział w obradach osób nieposiadających statusu posła.

Innym problemem związanym z elekcją marszałka była alternata prowincji, która miała zgłaszać jako pierwsza kandydata. Zdaniem Seredyki za czasów Wazów pierwszeństwo miała prowincja, z której pochodził marszałek „starej laski”. Według historyka było to prawdopodobnie spowodowane chęcią ,"neutralnego” zgłoszenia kandydatury ${ }^{49}$. Krytyczną polemikę z tezą Seredyki przedstawili Ochmann-Staniszewska i Staniszewski, których zdaniem pierwszeństwo zgłaszania kandydatów miały, również na zasadzie alternaty, wyłącznie dwa "górne” sejmiki koronne, czyli proszowicki i średzki. W przypadku nieobecności posłów sejmiku, któremu przypadało zgłaszanie kandydata, jego kolej przepadała, a kandydata na marszałka jako pierwszy miał proponować drugi „górny” sejmik koronny ${ }^{50}$.

Jeśli chodzi o kolejność zgłaszania kandydatów na marszałka w trakcie sejmów z lat 1669-1672, można zauważyć, że właściwa jest interpretacja Ochmann-Staniszewskiej i Staniszewskiego, choć z jednym zastrzeżeniem. W 1669 r. pierwszeństwo miał sejmik proszowicki. Został on zerwany, jednak zamiast przenieść prawo zgłoszenia kandydata na sejmik średzki, jako pierwszy kandydata na marszałka proponował przedstawiciel sejmiku zatorskiego - Jan Pieniążek ${ }^{51}$. Sytuacja powtórzyła się na drugim sejmie w 1670 r. $^{52}$ Wyrażenie zgody na zgłaszanie kandydatury przez posła z księstwa oświęcimsko-zatorskiego mogło być spowodowane tym, że sejmik zatorski również reprezentował województwo krakowskie i poseł z tej ziemi przed sejmem miał obowiązek stawić się na sejmiku proszowickim ${ }^{53} . Z$ powodu braku posłów wybranych w Proszowicach pierwszeństwo przeniesio-

47 Diariusz Seymu [drugiego]..., s. 889.

48 B. Ossol., 247, k. 214v: Diariusz sejmu warszawskiego...

49 J. Se redyka, Elekcje marszatków poselskich..., s. 102-103.

50 S. Ochmann-Staniszewska, Z. Stan iszewski, op. cit., s. 135-136.

51 Diariusz sejmu koronacyjnego..., s. 4.

52 Diariusz sejmu zwyczajnego 1670..., s. 4.

53 Świadczyć o tym może fragment diariusza sejmu koronacyjnego: „księstwo oświęcimskie, bo województwo krakowskie dla rozerwanego sejmiku posłów nie miało, według alternaty w[ojewó]dztwa krakowskiego mianowało $[\ldots]$ na dyrektorstwo [...]". Diariusz sejmu koronacyjnego..., s. 4. 
no na przedstawiciela drugiego sejmiku województwa krakowskiego. Takie rozwiązanie problemu sugeruje, że pierwszeństwo miały nie dwa "górne” sejmiki, a województwa i z tego też powodu pozwolono przedstawicielowi sejmiku zatorskiego zgłaszać jako pierwszemu kandydata na marszałka ${ }^{54}$.

W trakcie pierwszego sejmu w 1670 r. kandydata zgłaszał, zgodnie z alternatą, poseł województwa poznańskiego ${ }^{55}$. Na sejmie 1672 r. pierwszeństwo zgłoszenia kandydata przypadało po raz kolejny prowincji wielkopolskiej i propozycję kandydatury jako pierwszy zgłosił w imieniu województwa poznańskiego Jan Stanisław Korzeniowski ${ }^{56}$. Na drugim sejmie w 1672 r. pierwszeństwo w zgłaszaniu kandydata miało województwo krakowskie, jego przedstawiciele byli obecni na sejmie i jako pierwsi zgłaszali kandydata na marszałka ${ }^{57}$.

Ostatnią kwestią, będącą przedmiotem sporu wśród szlachty w XVII w., było wykorzystanie głosowania do wyboru marszałka, co de facto stanowiło wyłom w zasadzie jednomyślności. Zdaniem części szlachty w przypadku zgłoszenia kilku kandydatów jeden z nich powinien zostać wskazany na drodze dyskursu. Głosowanie było uznawane jedynie w celu sprawdzenia, który z nich ma największe poparcie przed jednomyślnym jego wyborem ${ }^{58}$. Tolerowano wybór większością głosów, ale najczęściej dążono do, nawet pozornej, zgody wszystkich na wybór danego kandydata ${ }^{59}$. Sposobem na jednomyślny wybór, w przypadku zgłoszenia kilku kandydatur, było zrzeczenie się głosów przez pozostałych kandydatów na rzecz tego z największą ich liczbą. Wielokrotnie nie dochodziło jednak do tej procedury, a marszałek wybrany większością głosów i tak zostawał uznany przez całą izbę ${ }^{60}$. Teoretycznie istniały trzy sposoby przeprowadzenia głosowania: głosowanie viritim, czyli oddawanie głosów przez poszczególnych posłów, głosowanie „przez województwa” i głosowanie „przez sejmiki” ${ }^{61}$. Zebrane dane z czasów Jana Kazimierza Wazy wskazują, że najczęściej przeprowadzane było głosowanie viritim $^{62}$.

Na sejmie koronacyjnym 1669 r. Jan Pieniążek zgłosił kandydaturę Piotra Korycińskiego, starosty rabsztyńskiego, na dyrektora izby. Ten jednak wymówił się od sprawowania funkcji. I wówczas zaproponowano kandydaturę Stanisława Krzyckiego, który nie miał

54 Zgłaszanie kandydatów przez dwa „górne” województwa koronne potwierdza również fakt, że w przypadku Wielkopolski kandydata na marszałka zgłaszali wyłącznie przedstawiciele województwa poznańskiego, mimo że na sejmiku proszowickim stawiali się także posłowie z województwa kaliskiego.

55 Diariusz sejmu nadzwyczajnego..., s. 8.

56 Diariusz sejmu zwyczajnego 1672..., s. 10.

57 B. Ossol., 247, k. 214v: Diariusz sejmu warszawskiego...

58 J. Seredyk a, Elekcje marszatków poselskich..., s. 105-107.

59 J. Seredyka, W. Kaczorowski, op. cit., s. 352.

60 J. Se redyka, Elekcje marszatków poselskich..., s. 111.

${ }_{61}$ W. Czapliński, Sejm w latach 1587-1696, [w:] Historia sejmu polskiego, t. 1: Do schytku szlacheckiej Rzeczypospolitej, red. J. Mi ich alski, Warszawa 1984, s. 250.

62 S. Ochmann-Staniszewska, Z. Staniszewski, op.cit., s. 142-144. 
kontrkandydatów i jednomyślnie został obrany marszałkiem. Sam Krzycki, zgodnie ze zwyczajem, oddał kurtuazyjnie „kreskę” na innego posła ${ }^{63}$.

W trakcie sejmu nadzwyczajnego w $1670 \mathrm{r}$. zaproponowano dwie kandydatury: Marcjana Ogińskiego, krajczego litewskiego, i Jana Kazimierza Kierdeja, marszałka grodzieńskiego. Co ciekawe, zarówno posłowie województwa poznańskiego, jak i krakowskiego zgłosili pierwszą z przedstawionych kandydatur, zaś osobę Kierdeja zaproponował Jan Pieniążek. Według Karola Bobiatyńskiego Ogiński był kandydatem opozycyjnym, zaś Kierdej, należący do stronnictwa Paców, został wybrany przez stronnictwo dworskie ${ }^{64}$. Trzecim, mało znaczącym kandydatem, był Benedykt Sapieha, stolnik litewski. Stosunkiem głosów 40 do 39 zwyciężył Kierdej ${ }^{65}$. Oznaczało to bardzo nieznaczne zwycięstwo dworu w walce o laskę marszałkowską, co nie zdarzało się do tej pory zbyt często i świadczyło o sile opozycji w izbie.

W roku 1670 na stanowisko marszałka zaproponowano dwie kandydatury: Stanisława Herakliusza Lubomirskiego i Jana Pieniążka. Sytuacja była o tyle prosta, że drugi z kandydatów zaproponował Lubomirskiego i zrzekł się poparcia dla siebie na jego rzecz. W tej sytuacji przeprowadzone następnie głosowanie było już tylko formalnością. W diariuszu znajdujemy informację, że „nemine contradicente wszystkie [kreski] szły po województwach na niego" 66 .

W przypadku elekcji na pierwszym sejmie w 1672 r. najpierw została zgłoszona kandydatura Stefana Sarnowskiego, podkomorzego łęczyckiego, ale ten zrezygnował z dyrektorstwa ze względu na słaby stan zdrowia. Wtedy zgłoszono kandydaturę Marcina Oborskiego. Nie miał on konkurentów i został jednomyślnie wybrany przez całą izbę. Tylko sam Oborski oddał głos na innego posła, ale ten, zgodnie z przyjętym zwyczajem, zrzekł się „kreski”, aby zachować jednomyślność wyboru. Głosowanie odbywało się „per ordinem województw" ${ }^{67}$. W przypadku sejmu nadzwyczajnego w 1672 r. kandydatura Sokolińskiego była jedyną znaczącą i został on jednomyślnie obrany marszałkiem ${ }^{68}$.

W trakcie panowania Michała Korybuta nadal w żaden sposób nie unormowano prawnie procedury elekcji marszałka. Można jednak zauważyć, że przebiegała ona zgodnie z praktyką sejmową lat wcześniejszych. Oznacza to pewnego rodzaju kontynuację dotychczasowej tradycji i dowodzi, że wybrane do analizy elementy procedury sejmowej w czasach panowania Michała Korybuta nie uległy praktycznie żadnym zmianom.

63 Diariusz sejmu koronacyjnego..., s. 4-5.

${ }^{64}$ K. B obiatyński, W walce o hegemonię. Rywalizacja polityczna w Wielkim Księstwie Litewskim w latach 1667-1674, Warszawa 2016, s. 98.

65 Diariusz sejmu nadzwyczajnego..., s. 8.

66 Diariusz sejmu zwyczajnego 1670..., s. 4.

${ }_{67}$ Diariusz sejmu zwyczajnego 1672..., s. 10.

68 „Szły tedy kreski nieprzerwanie, y zgodnie wszytkie na JmćPa Sokolińskiego, Pisarza WXL”. Diariusz Seymu [drugiego]..., s. 889. 
Karolina Leśniak

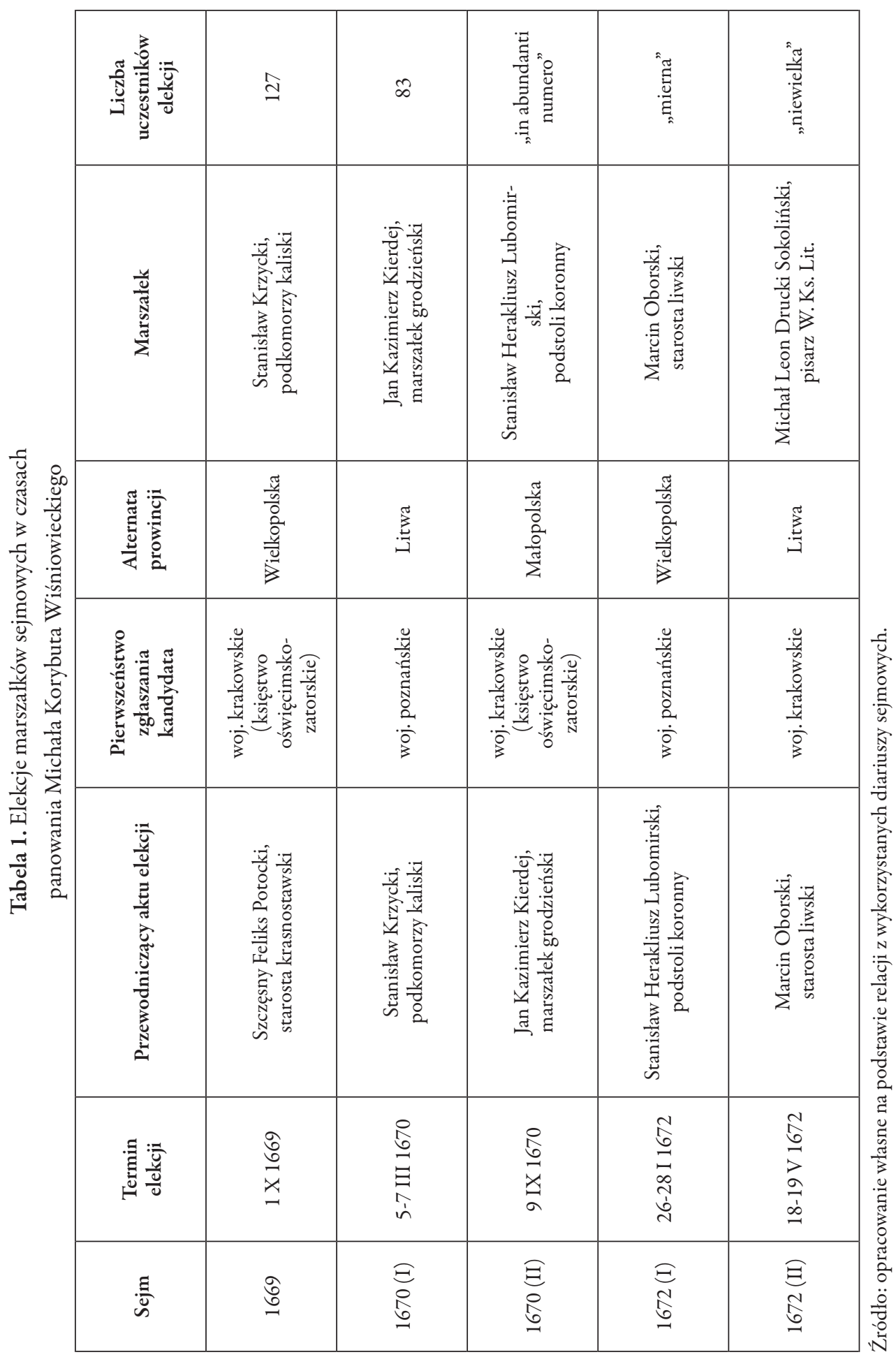


Przedstawione powyżej problemy stanowią wstęp do dalszych analiz. Choć część przedstawionych powyżej ustaleń zdaje się dość dobrze udokumentowana, to pewne doprecyzowanie uzyskanych wyników będzie możliwe przez poszerzenie materiału źródłowego. Może to dotyczyć problemów związanych z przewodnictwem aktu elekcji czy frekwencją poselską. Pozwoli to również na inne analizy, związane choćby z rolą poszczególnych stronnictw politycznych w forsowaniu własnego kandydata do objęcia funkcji marszałka. Wymaga to jednak dalszych studiów i przede wszystkim poszukiwań źródłowych. Umożliwią one szerszą analizę porównawczą zarówno tego, jak i innych elementów procedury parlamentarnej z czasów panowania Michała Korybuta Wiśniowieckiego.

\section{BIBLIOGRAFIA}

\section{Źródła rękopiśmienne:}

Diariusz sejmu warszawskiego zaczętego in Anno 1672 die 18 Maii, Biblioteka Zakładu Narodowego im. Ossolińskich we Wrocławiu, 247.

\section{Źródła drukowane:}

Chrapowicki J. A., Diariusz. Częśćtrzecia: lata 1669-1673, oprac. L. A. Wierzbicki, Warszawa 2009. Diariusz sejmu koronacyjnego 1669 roku, oprac. K. Przyboś, M. Ferenc, Kraków 2004.

Diariusz sejmu nadzwyczajnego 1670 roku, oprac. K. Przyboś, M. Ferenc, Kraków 2004.

Diariusz sejmu zwyczajnego 1670 roku, oprac. K. Przyboś, M. Ferenc, Kraków 2005.

Diariusz sejmu zwyczajnego 1672 roku, oprac. K. Przyboś, Kraków 2007.

Diariusz Seymu [drugiego] Roku Tysiąc Sześćset Siedmdziesiąt wtórego, miesiąca Maja, dnia ośmnastego, [w:] Pisma do wieku i spraw Jana Sobieskiego, t. I, cz. 2, oprac. F. Kluczycki, Kraków 1881, s. 887-950.

[Inny, krótszy dziennik Sejmu styczniowego, r. 1672], [w:] Pisma do wieku i spraw Jana Sobieskiego, t. I, cz. 2, oprac. F. Kluczycki, Kraków 1881, s. 838-846.

Volumina legum, t. V, Warszawa 1859.

\section{Opracowania:}

Bobiatyński K., W walce o hegemonię. Rywalizacja polityczna w Wielkim Księstwie Litewskim w latach 1667-1674, Warszawa 2016.

Czapliński W., Sejm w latach 1587-1696, [w:] Historia sejmu polskiego, t. 1: Do schytku szlacheckiej Rzeczypospolitej, red. J. Michalski, Warszawa 1984, s. 217-299.

Dorobisz J., Z problematyki procedury sejmów nadzwyczajnych za Zygmunta III, [w:] Studia zdziejów Rzeczypospolitej szlacheckiej, red. K. Matwijowski, Z. Wójcik, Wrocław 1988, s. 133-137, Acta Universitatis Wratislaviensis, nr 945, Historia, t. 66.

Kaczorowski W., Wybór marszatków poselskich na sejmach bezkrólewia 1632 roku, „Zeszyty Naukowe WSP w Opolu. Historia” 1986, t. 23, s. 33-41.

Kołodziej R., Elekcje marszatków poselskich w czasach panowania Jana III Sobieskiego (1676-1695), [w:] Ustrój - polityka - kultura. Studia ofiarowane Profesor Stefanii Ochmann-Staniszewskiej, red. J. Maroń, R. Kołodziej, Wrocław 2011. 
Ochmann-Staniszewska S., Staniszewski Z., Sejm Rzeczypospolitej za panowania Jana Kazimierza Wazy. Prawo - doktryna - praktyka, t. 2, Wrocław 2000.

Olszewski H., Sejm Rzeczypospolitej epoki oligarchii 1652-1763. Prawo - praktyka - teoria - programy, Poznań 1966.

Seredyka J., Elekcje marszatków poselskich za Zygmunta III Wazy (1587-1632), [w:] Studia z dziejów Rzeczypospolitej szlacheckiej, red. K. Matwijowski, Z. Wójcik, Wrocław 1988, s. 95-112, Acta Universitatis Wratislaviensis, nr 945, Historia, t. 66.

Seredyka J., Marszatkowie izby poselskiej za Zygmunta III Wazy, [w:] Wtadza i spoteczeństwo w XVI i XVII w. Praca ofiarowana Antoniemu Mączakowi w sześćdziesiata rocznice urodzin, red. M. Kamler [et al.], Warszawa 1989.

Seredyka J., Kaczorowski W., Marszatkowie poselscy za Wtadystawa IV, [w:] Kultura, polityka, dyplomacja. Studia oflarowane Profesorowi Jaremie Maciszewskiemu w sześćdziesiąta rocznice jego urodzin, red. A. Bartnicki [et al.], Warszawa 1990, s. 346-363.

Stolicki J., O wyborze marszatka poselskiego podczas sejmu elekcyjnego 1669, [w:] Poprzez stulecia. Ksiega pamiatkowa ofiarowana profesorowi Antoniemu Podrazie w 80. rocznice Jego urodzin, red. D. Czerska, Kraków 2000.

Uruszczak W., Sejm walny koronny w latach 1506-1540, Warszawa 1980.

Wierzbicki L. A., Marszatkowie i parlamentarzyści. Studia z dziejów sejmu polskiego w XVII w., Warszawa 2014.

Wierzbicki L. A., O zgodę w Rzeczypospolitej. Zjazd warszawski i sejm pacyfikacyjny 1673 roku, Lublin 2005. 